\title{
The Politics of the Commons: Reform or Revolt?
}

\author{
Vangelis Papadimitropoulos \\ University of Crete, Greece, vagpap78@hotmail.com
}

\begin{abstract}
In this paper I present a critical overview of the contemporary political theories of the Commons, classified in three main categories: 1) the liberal 2) the reformist and 3) the anti-capitalist. Advocates of the liberal theory of the Commons take a stand in favour of the coexistence of the Commons with the state and the market. The reformists argue for the gradual adjustment of capitalism to the Commons with the aid of a partner state, while the anti-capitalists contrast both the liberals and the reformists by supporting the development of the commons against and beyond capitalism. I make the case that both the liberal and the anti-capitalist theorists miss the likelihood of technology rendering redundant large-scale production in the future, and forcing thus capitalism to adjust to the Commons in the long run. The prospect, therefore, of an open cooperativism, introduced by the reformist theory, holds significant potential with respect to the future development of the Commons. For the Commons to expand and flourish, however, a global institutional reform, based on a number of trans-local and transnational principles, is sine qua non. Hence, transparency of information, distribution of value, solidarity and bottom-up self-management are the core variables of individual and collective autonomy inasmuch as they permit a community or group to formulate its values in relation to the needs and skills of its members.
\end{abstract}

Keywords: the Commons, Liberal Theory, Reformist Theory, Anti-Capitalist Theory, Transparency

\section{Introduction}

The development of information and communication technologies in the last decades has supported an alternative economic paradigm, termed the Commons, which disrupts the capitalist mode of production. Alongside the natural Commons scrutinised by Ostrom, the Internet and free and open-source software and hardware are prominent cases of digital Commons, highlighted by Benkler. Both 'analogue' and digital Commons consist in the peer-to-peer production of value on the basis of distributed or common property infrastructures (natural resources, technology, knowhow, capital, culture), self-managed by their user communities in accordance to democratically established rules or norms. It is argued that the Commons favour decentralisation over central control, self-governance over hierarchical management, access over property, transparency over privacy, distribution of value over profit maximisation, sustainability over growth at all costs (Ostrom 1990; Benkler 2006; Bollier and Weston 2012; Bauwens and Kostakis 2014).

In the first section, I present the theses of the three main contemporary theories of the Commons: the liberal, the reformist and the anti-capitalist. The criterion by which I make this classification is the position in which these theories place the Commons with respect to the relation of the latter to the state and market operation. Whereas the liberal theory places the Commons between the state and the market, the reformist theory argues for the reforms necessary that could force capitalism to adjust to the Commons in the long run. In contrast to both the liberal and the reformist, the anti-capitalist theory supports the development of the Commons 
against and beyond capitalism. In the second section, I develop a critical stance to all three theories with the aim to provide with a constructive synthesis of the politics of the Commons.

\section{The Politics of the Commons}

The Commons movement is grounded on a political theory, the roots of which can be traced back to the transition from feudalism to capitalism. The unfulfilled goal of the social movements for freedom of the $15^{\text {th }}, 16^{\text {th }}$ and $17^{\text {th }}$ centuries (Corcoran 1983; Linebaugh and Rediker 2000; Federici 2004) resonates in the modern politics of the Commons, developed in the Ricardo school of socialists and the work of SaintSimon, Fourier, Proudhon and Marx. Since then, a number of thinkers have connected their work with the Commons: Arendt, De Beauvoir, Latouche, Gorz, Chomsky, and Castoriadis, to name just a few. Nowadays, there are three main theoretical approaches to the Commons: a liberal (Ostrom, Benkler, Bollier), a reformist (Bauwens and Kostakis, Arvidsson and Peitersen, Rushkoff) and an anticapitalist (Hardt and Negri, De Angelis, Caffentzis, Federici, Rigi, Meretz). The above classification is but a schematic one. As such, it is devoid of any crude ideological labelling. I should mention, finally, that I am referring here only to the most influential thinkers of the Commons.

\subsection{The Liberal Theory of the Commons}

For the sake of clarity, we have to distinguish initially between the neoliberal cooptation of the Commons and the liberal theory of the Commons. Whereas the former refers to a strategy of the capital to neo-feudalise the Commons under the marketing buzzword of a so-called 'sharing' economy (as for Uber, Airbnb, Taskrabbit and so on) that supposedly renders everybody a micro-entrepreneur, trading, sharing, swapping and renting the excess capacity of products and services online (Scholz 2012; Scholz and Schneider 2016), the latter refers to theories of the Commons which examine their potential for a genuine sharing economy based on peer-to-peer production. The criterion by which I classify the work of Ostrom, Benkler and Bollier under the term 'liberal' is that all three place the development of the Commons in parallel with the state and market operation. They advocate the coexistence of the Commons with the public (its associated state and institutions) and private sector.

To begin with, Ostrom's work on the Commons can be broadly situated among the rational-choice tradition in economic and political theory, focusing on the impact of incentives on the functioning of institutions. Hardin (1968) emphasised the problem of the free-rider with regards to the management of common pool resources. He calls us to picture a pasture open to all, in which each herder acts as a self-interested actor, aiming to maximise his gain by adding more and more animals for grazing. This eventually results in overgrazing and pasture depletion. He concludes that the most efficient solution to "the tragedy of the commons" is privatisation. Accordingly, Hardin's metaphor of the grazing commons applies to all situations where the "tragedy of the commons" is possible. Therefore, Hardin's argument is consistent with the prevailing neoliberalism of our times (Castree 2010,14).

Hardin's argument, however, is problematic on two interdependent accounts. Firstly, he utilises a limited view of private property rights and, secondly, he refers to open access commons with no rules at all regulating the use of the resource. But this is not always the case. Ostrom was awarded the Nobel Prize in economics in 2009 for having analysed numerous successful cases of self-managed natural resources 
such as forests, fisheries, pastures and irrigation fields, stretching across the globe from Switzerland to Spain, Nepal and Indonesia (Ostrom 1990). In all the above cases, the self-interest of the farmers has been integrated into the cooperative logic of the community. Private property rights have combined with common property regimes for centuries. In the Swiss Alps, for example, plots have been owned individually by farmers, while the summer meadows, forests, irrigation systems and the paths and roads connecting individually and communally owned plots are managed collectively (Ibid., 61-5). Mixed regimes of private and common property apply in cases with no clear boundaries, or with a cultural hostility to private property rights. On the other hand, private property rights are most effective in cases where there are clear boundaries to a resource, and the community is highly mobile and heterogeneous.

Hardin also neglects the fact that there are numerous examples where privatisation or government regulation of common pool resources have had disastrous consequences, owing to rent-seeking mechanisms of the market combined with government corruption and deficient knowledge of particular circumstances in time and place (Van de Walle 2001; De Alessi 1998). In contrast, Ostrom's work on the Commons helped move away from the fruitless dichotomy between "privatisation" and/or "government regulation" by pointing to "polycentric" systems of governance, where "a rich mixture of public and private instrumentalities" is employed across a vast diversity of institutions (Ostrom 2012, 60-61): "We have found that government, private and community-based mechanisms all work in some settings" (Ibid., 70). Polycentricity refers to autonomous and overlapping decisioncentres related to certain types and scales of resources. For example, the large scale of climate change demands the involvement of all three sectors (public, private and the Commons). Polycentricity differs from anarchy in that common pool resources are governed by well-established rules. After extensive field observations, Ostrom came up with a set of design principles regulating the Commons, such as the demarcation of clear boundaries, the matching of the rules with local needs and conditions, the modification of the rules by those directly involved, the monitoring of resources and the imposition of sanctions on free-riders.

As such, Ostrom's work on the Commons belongs to the liberal tradition for multiple reasons. Firstly, she adheres to the liberal theory of private property rights, dating back to Hobbes and Locke. Yet, in Ostrom, private property rights do not necessarily equate to individual property rights, but can relate to mixed regimes of private and common property rights. Secondly, she analyses common pool resources through the lens of rational-choice theory, which employs the methodological individualism of liberalism, evolving from Hume and Bentham's utility theory into the neoclassical economics of our times. She challenges, however, the conventional analysis of institutions in that she considers incentives much more complex and varied than a zero-sum game. Like Sen (1977), Ostrom rejects the idea that rationality consists solely in selfishness and opportunism. Economic behaviour has been always dependent not only on competition but also on cooperation in solving day-to-day collective problems (Ostrom 2000, 143). Nonetheless, Ostrom's work is in tune with the liberal tradition given that she places the development of the Commons in parallel with the state and market operation.

Benkler's approach of the Commons can also be related to the liberal tradition. Benkler builds on Castells' concept of the networked society, which marks the shift from groups and hierarchies to networks as social and organisational models (Castells 2000; 2009). Benkler analyses, in particular, the effect of information and 
communication technologies on the development of a nonmarket sector of information, knowledge and cultural production, not treated as private property but as an ethic of open sharing and cooperation (2006, 59-90). The Internet, free and opensource software, and mobile applications have significantly reduced transaction costs, thus unleashing an excess capacity for decentralised social production, manifested in the creation of numerous distributed computing projects (such as Wikipedia, Massive Multiplier Online Games, Open Directory Project, and Project Gutenberg) and file-sharing networks (Kazaa, Napster, etc.). Benkler defines this new model of social production as Commons-based peer production, intended to enhance the core values of liberal societies - individual freedom, a more participatory political system, a critical culture and social justice.

In addition to the reduced transaction costs from the use of information and communication technologies, the key feature of the digital Commons is the non-rival characteristic of information. Unlike private goods, an e-book, a PDF file, a movie or an mp4 can be used by two users simultaneously:

"The salient characteristic of commons, as opposed to property, is that no single person has exclusive control over the use and disposition of any particular resource in the commons. Instead, resources governed by commons may be used or disposed of by anyone among some (more or less well-defined) number of persons, under rules that may range from 'anything goes' to quite crisply articulated formal rules that are effectively enforced" (Benkler 2006, 61).

Like local Commons, digital Commons can be both public and private in that anyone can build on another's contribution, extend it and make it their own. Yet the digital Commons are not limited to local Commons, which are governed by a stable community of individuals interacting often and knowing each other. They break the limits of time and space, thereby allowing more people to participate in social production worldwide. Nowadays, especially, we are witnessing the emergence of a platform cooperativism allowing several groups (taxi drivers, photographers, farmers, designers, programmers, teachers, researchers, innovators, investors, web developers, etc.) to come together (either online, offline or both) and work in a selfmanaged and autonomous manner.

However, Benkler argues that decentralised social production cannot apply to large-scale material goods like the manufacturing of automobiles, steel or airplanes. He therefore places Commons-based peer production in between the operation of the state and the market: "I treat property and markets as just one domain of human action, with affordances and limitations. Their presence enhances freedom along some dimensions, but their institutional requirements can become sources of constraint when they squelch freedom of action in nonmarket contexts. Calibrating the reach of the market, then, becomes central not only to the shape of justice or welfare in a society, but also to freedom" (Benkler 2006, 20). The role of the state is then to calibrate the reach of the market with respect to the nonmarket contexts of Commons-based peer production. Benkler holds that Commons-based peer production is a better provider of freedom and autonomy than the market and the state. He therefore limits the role of the state to securing "network neutrality" with respect to market operation and the Commons. 
Benkler's theory of freedom differs from Kant's or Rawls' formal theories of freedom that assign to the state a regulatory or distributive role with regards to market operation. Benkler's approach is much closer to Habermas' work in that he describes a new model of social production pertaining to civil society per se. Commons-based peer production is a third mode of production that broadens the scope of individual and collective autonomy by surpassing the limits of both the market and the state. In particular, decentralised nonmarket production alters the constraints existing in the producer/consumer relationship by blurring the boundaries between production, consumption, work and play through the genesis of the "user" who becomes a more active participant in the creation of culture, entertainment and information (Benkler 2003,1268 ). Benkler abides by the liberal notion of negative freedom inasmuch as he conceives of the Commons as an alternative institutional space providing a wider diversity of constraint with respect to the state and the market: "Freedom inheres in diversity of constraint, not in the optimality of the balance of freedom and constraint represented by any single institutional arrangement" (Benkler 2006, 145-146). In contrast to positive conceptions of freedom formulated by the central authority of the state, the Commons provide a much broader spectrum of choices for the individual to act alone or in loose affiliations with others. The role of the law in such circumstances would then be to implement policies that diversify the set of options available to all (Ibid., 152). In this sense, Commons-based peer production is compatible with various theories of democracy and justice in the liberal tradition (Ibid., 184-185, 303308; Benkler 2003).

Bollier's model of "green governance" can also be embedded in the liberal tradition. Bollier articulates a new architecture of policy and law to support the Commons, which are defined as shared resources managed democratically by their users' community (Bollier and Weston 2012, 343-352). At the level of selfgovernance of the Commons, he adheres to Ostrom's design principles. At the level of macro-policy, like Ostrom and Benkler, he places the Commons in parallel with the state and the market: "The overall goal must be to reconceptualise the neoliberal State/Market as a 'triarchy' with the Commons - the State/Market/Commons - to realign authority and provisioning in new, more beneficial ways. The State would maintain its commitments to representative governance and management of public property just as private enterprise would continue to own capital to produce saleable goods and services in the Market sector" (Ibid., 350). But, following Bauwens, he claims that the State must shift its focus to become a Partner State not only of the Market sector but also of the Commons sector (Ibid.). Thus the State must play a more active role in establishing and overseeing large-scale common pool resources such as the atmosphere, oceanic fisheries, hard and soft minerals, timber, public lands, national parks and wilderness areas, rivers, lakes and other bodies of water (Bollier and Weston 2012).

With regards to the law, Bollier advocates the inversion of the purposes of the conventional private contract and property law to serve collective rather than individual interests. The most famous example of such an inversion is the General Public License (GPL) (Ibid., 350). New property regimes could combine with "stakeholder trusts" and digital networking technologies, with the mission to sustain a more transparent, participatory and accountable Commons (Ibid., 350-351). Finally, Bollier has demonstrated a variety of proposals for the democratic finance of the Commons: social and ethical lending by credit unions and public banks, crowdfunding of the Commons (Goteo), complementary currencies, time banks, and so on (Conaty and Bolliers 2015). 


\subsection{The Reformist Theory of the Commons}

Bauwens and Kostakis build on the work of Ostrom and Benkler, but they differentiate from both in that they intend to reform capitalism to the extent that the latter will be forced to adjust to the Commons in the long run. Bauwens and Kostakis' argument echoes Marx's claim that capitalism is doomed to failure as the evolution of technology reduces the costs of production to the level that capitalism cannot sustain itself in the long run. Technology undermines capitalism inasmuch as it makes workers redundant for the reproduction of production. But in contrast to Marx's ambivalence with regards to cooperatives, Bauwens and Kostakis hold that the Commons can replace capitalism from within, just as capitalism did with feudalism. Instead of a revolutionary party capturing state power first and implementing central planning of production thereafter, with the long-term mission to establish communism, they argue in favour of a reformism that will force capitalism to adjust to the Commons in the long run. Commons-based peer production can beat capitalism on its own ground: that is, competition. Technology can render the Commons more competitive in relation to capitalism and pave the way for a post-capitalist ethical economy supported by a partner state.

Commons-based peer production is based on the free cooperation of users who produce value on the basis of distributed "fixed" capital or common property regimes (Bauwens 2005). By "fixed capital" Bauwens refers basically to computers and software. Internet and the invention of free and open software and hardware are pivotal to the development of peer-to-peer production, since they allow for the autonomy of distributed networks that are not controlled by hubs; that is, centralised choke-points.

Peer-to-peer production is furthermore characterised by equipotentiality, holoptism and stigmergy. Equipotentiality opens up equal opportunities for everyone to participate according to his/her skills. Participation is conditioned a posteriori by the process of production itself, where skills are verified and communally validated in real time. Holoptism contrasts panopticism that penetrates the modern systems of power (Foucault 1977) in that it allows participants free access to all information necessary for the accomplishment of the project in question. Access is permitted not in terms of privacy, but in terms of the overall contribution of the participants to the aims, metrics and documentation of the project as a whole. Holoptism allows thus for stigmergic processes of mutual coordination where the participants can match their contributions to the needs of the system (Bauwens 2005).

Bauwens and Kostakis' political economy of peer-to-peer production is based on a philosophy of history penetrated by a mix of Schumpeterian and Marxian insights: they adhere to a "teleological" account of history, determined by successive technoeconomic shifts in the modes of production and exchange. In Network Society and Future Scenarios for a Collaborative Economy, Bauwens and Kostakis incorporate their analysis of peer-to-peer production into a neo-Schumpeterian narrative, developed in particular by Carlota Perez, in which economic crises, triggered by technological innovation, are an inherent characteristic of capitalism, forcing it to progress overtime (Kostakis and Bauwens 2014, 2-14). Technological innovation drives capitalism's development into a spiral of upswings and downswings, lasting approximately 40-60 years until the next one "takes off" (Perez 2002, 15).

Bauwens and Kostakis hold that global economy is now at the turning point of a novel technological revolution, where three different value models are competing for dominance: traditional capitalism, neo-feudal cognitive capitalism and Commonsbased peer production (Kostakis and Bauwens 2014, 10-14; Bauwens 2014a). 
Traditional capitalism is in decline, since it suffers from an irreversible contradiction: it aims at infinite growth in a finite planet, causing both economic and ecological crisis. Neo-feudal cognitive capitalism splits into netarchical capitalism (Facebook, Google, Yahoo, Airbnb, Uber, etc.) and anarcho-capitalism or distributed capitalism (Bitcoin, Kickstarter, etc.). "While netarchical capitalism mainly exploits human cooperation, distributed capitalism is premised on the idea that everybody can trade and exchange; or, to put it bluntly, that 'everyone can become an independent capitalist' " (Kostakis and Bauwens 2014, 31).

Neo-feudal cognitive capitalism creates an increased contradiction between a decentralised peer-to-peer production and a centralised profit accumulation. Technology enhances the production of an abundance of decentralised use value, which cannot fully translate into exchange value, thus undermining the very foundation of capitalism, that is, profit maximisation. Innovation becomes social by diffusing through peer-to-peer networks, and capital becomes an a posteriori intervention rather than an a priori condition of innovation (Ibid., 28-29). Therefore, neo-feudal cognitive capitalism produces a value crisis for both capital and labour, reintroducing anew the Marxian argument that technological progress is antagonistic towards profit rates. According to Bauwens and Kostakis, this unsustainability of contemporary value flows can be counteracted by the innovative social relations of the Commons economic anti-paradigm, supported by information and communication technologies (Bauwens and Niaros 2017).

Commons-based peer production develops at the edges of traditional and neofeudal cognitive capitalism, challenging both simultaneously. The Commons favours decentralisation over central control, democratic self-management over hierarchical management, access over ownership, transparency over privacy, and environmental sustainability over growth at all costs. As such, the Commons splits into local and global.

Local Commons refer to autonomous peer-to-peer projects developed by resilient communities: community land trusts offering affordable housing and social care services, degrowth ecological and permaculture movements, Transition Towns, the Bologna project, car sharing, interest-free banks, autonomous energy production, and so on (Bollier and Helfrich 2015). But local Commons seem more like centripetal lifeboat strategies that cannot but conform to the mainstream of capitalism in the long run. For this reason, Kostakis and Bauwens argue that local Commons need to connect to global Commons $(2014,48)$.

The key factor in the development of the global Commons is the invention of free software. Whereas traditional capitalism is based on artificial scarcity, market pricing, profit maximisation and top-down management, free software supports a peer-topeer production aiming at the distribution of value through hybrid forms of governance, where hierarchy, autonomy and cooperation coexist on multiple degrees and levels (Kostakis and Bauwens 2014, 52; Benkler 2006). Some examples of the global Commons are: Wikipedia, Wikispeed, FLOSS, Open Source Ecology, LibreOffice, Linux, Goteo, FarmHack, Arduino, Espiral, Loomio, and Sensorica (Bollier and Helfrich 2015). Blockchain technology (Swan 2015) can potentially foster the Commons development inasmuch as it can provide decentralised and transparent self-management of eco-systemic networks (holoptism), operating through mutual coordination (equipotentiality and stigmergy) on the basis of open design, open manufacturing, open distribution, open-book accounting, open supply chains, open finance, and so on. 
Bauwens and Kostakis incorporate Karatani's post-Marxist theory of modes of exchange into their philosophy of history (Bauwens 2016). Karatani criticises Marx's materialist philosophy of history as mistaken. Instead of world history being the product of the technological evolution of the modes of production sustaining the economic base of society's ideological superstructure, Karatani argues that the structure of world history is rather determined by modes of exchange. Instead of world history being the sequence of primitive communism, Asiatic despotic state, feudalism and capitalism, transcending classical slavery into serfdom and wage labour respectively, world history consists in the circulation of four modes of exchange: 'pure gift' of pooling and 'gift based on reciprocity' mode (nomads and clan societies), plunder and distribution (state), commodity exchange (capitalism) and mode $X$ that transcends all three as the restoration of mode A. Historically, all social formations consist of these four modes of exchange, with one being dominant at a time. Religion, the nation, socialist movements and cooperatives can be considered the most profound restorations of the reciprocity of the gift at the level of the capitalist state (Karatani 2014).

In accordance with Karatani's theory, Bauwens and Kostakis claim that peer-topeer production bears the potential to represent the transcendence of the trinity Capitalism-State-Nation as the restoration of the pure gift of pooling in the form of the Commons, supported by the Internet and free software. In this sense, the Commons could become the institutional restoration of a communal sharing, based on the principle: 'from each according to his/her abilities, to each according to his/her needs'. Whereas peer-to-peer production implies a sort of 'gifting', this does not create a contrary obligation. We would rather refer to peer-to-peer production as a form of semi-regulated cooperative voluntarism, which echoes Lessig's concept of the free "remix culture" $(2006,194)$. Peer-to-peer production is neither a hierarchyless nor structureless mode, but rather a mixed form of hierarchy, cooperation and autonomy. For instance, Wikipedia is a mixed form of democracy, aristocracy and monarchy. Democratic voting with regard to the content is accompanied by the aristocracy of the most reliable users and the monarchy of the founder/leader in cases where neither solely democracy nor aristocracy works. But still the Commons-based peer production needs major political reformations to become a dominant mode of production and exchange.

For this reason, Bauwens and Kostakis articulate a Commons-oriented political economy, advancing an open cooperativism between a partner state, ethical market entities (Bauwens 2014a) and the Commons, with the aim to gradually replace the accumulation of capital with the circulation of the Commons. The central axis of this open cooperativism would be the multi-stakeholder cooperative, which crystallises the values of a self-managed democratic community of investors, produsers and prosumers. Multi-stakeholder cooperatives would serve as the transition business model until ethical market entities fully adjust to the Commons in the long term.

The role of the partner state is of paramount importance, since it could boost the transition from capitalism to the Commons via a de-bureaucratisation and commonification of the public sector on the basis of a bottom-up self-management, establishing an open cooperativism between the Commons and ethical market entities willing to minimise negative social and environmental externalities. To this end, taxation of social/environmental entrepreneurship, ethical investing and productive labour should be minimised, whereas taxation of speculative unproductive investments, unproductive rental income and negative social and environmental externalities should be increased (Kostakis and Bauwens 2014, 66-67; Bauwens, 
Kostakis and Pazaitis 2016; Bauwens 2014a). In addition, education and publiclyfunded research and innovation could be aligned with the Commons-oriented economic model (Kostakis and Bauwens 2014, 68). Finally, Kostakis and Bauwens introduce a Peer Production License (PPL) - designed and proposed first by Kleiner (2010) - which is based on the principle that ethical market entities that would like to use the Commons without contributing should pay a license fee as a form of direct reciprocity. Peer Production Licensing (PPL) differs from Creative Commons Licensing in that it permits the commercialisation of one's work rather than providing a more agile copyright protection. Instead of capital capturing the use value of the Commons by means of the General Public License (as with, e.g., IBM), the PPL allows for the renting of the Commons knowledge. This way, a stream of income would be directed from ethical market entities to the Commons, securing the autonomy of the Commons per se (Kostakis and Bauwens 2014, 63-67).

Bauwens and Kostakis are aware of the contradictions of the partner state theory and the risks of commons co-optation by capital. This is why they argue for the creation of a global counter-hegemonic power that consists of three institutions operating at a translocal and transnational level: 1) a Chamber of Commons, locally representing commons-oriented entrepreneurial coalitions 2) an Assembly of the Commons bringing together commoners and citizens, also locally 3 ) a Commonsoriented Entrepreneurial Association, connecting commons-oriented enterprises globally (Bauwens 2016). In this framework, what Bauwens and Kostakis consider as reformism is a radical democratic self-institutionalisation of society via the model of an open-cooperativism, which aims at gradually adjusting the state and the cooperative and solidarity economy to the Commons-based peer economy. Seed forms of the model of open cooperativism can be today considered in the following translocal and transnationally operating coalitions: Enspiral (originally based in New Zealand); Sensorica (originally based in Montreal, Canada); Las Indias (mostly based in Spain but with many Hispanic members from Latin America); and Ethos VO (based in the UK).

In a similar vein, Arvidsson and Peitersen build on Hardt and Negri's notion of the multitude, according to which Marx's theory of value no longer holds. They consider the multitude as composed of a multiplicity of actors who create a number of common resources, monetised in the form of intangible or immaterial assets, as in the case of the social media or renting economies. Today, information and communication technologies blur the boundaries of the workplace, the public and the private sphere. Value thus evolves from an equation of labour time into a complex web of actions, operating both inside and outside the conventional setting of the factory. Value has transformed into an affective investment of financiers, brands, employers, prosumers, freelancers, activists and communities.

Arvidsson and Peitersen (2013) illustrate an ethical economy of productive publics, consisting in collaborative networks of peer-to-peer producers, supported by Internet and mobile applications that can enhance an economic democracy in which the universal measure of value is the general sentiment. Affect refers to the Spinozian power to act, evolving into the Nietzschean power as desire, which penetrates a vast part of postmodern thought (Negri 1999). Value as affect departs from a simple labour task or motivation of the employee, leading to a sophisticated innovation, a brand loyalty built on reputation, a self-fulfilling prophecy of the market, the likes of the social media, a political choice, and so on (Arvidsson and Peitersen 2013, 140142). Value has transformed into a convention based on an interpretation that reduces complexity. In short, value is the affective investment of the public in the 
intersubjective creation of 'truth, beauty and utility'. Thus, Arvidsson and Peitersen demonstrate a technologically advanced Habermasian transformation of the public sphere, which would supposedly open up a more rational and democratic negotiation of economic value, bringing together politics, the Commons and a reformed capitalism.

From a more 'digital' perspective, Rushkoff agrees with Bauwens and Kostakis that corporatism is caught up in a growth trap inasmuch as it aims at infinite growth in a finite planet. But we are today on the verge of a structural breakdown, as corporatism - enhanced by digital industrialism - runs out of places from which to extract value for growth. Moreover, financialisation has led to a complete disconnect between capital and value. As a result, Schumpeter's creative destruction process may turn into a destructive destruction pushing corporatism toward hybrid business models that favour a more sustainable and social approach to enterprise (Rushkoff 2016, 100). As Rushkoff remarks: "The only lingering question is whether it's simply a cycle repeating itself or a unique and unprecedented challenge to our economic operating system" (Ibid., 98). This question is all the more important in the case of digital industrialism, which aims at putting humans out of the equation, creating the danger of causing a permanent consumer shortage.

Rushkoff argues that corporations are a type of software that need to be recoded on the model of digital distributism akin to Bauwens and Kostakis' model of open cooperativism. Like Bauwens and Kostakis, he holds that the centralised corporate model is being disrupted and in some cases replaced by the distributed peer-to-peer production (Ibid., 102). He points then to concrete structural reforms that could help corporatism adjust to distributed peer-to-peer production in the long term. Specifically, he proposes a hybrid business model of cooperation between corporations and the Commons in the form of a "benefit corporation" where the pursuit of growth is subsumed to a sustainable economy based on value creation and the recycling of money. The "benefit corporation" model would be framed by nonprofit and social enterprises, crowdfunding, local currencies, time banks and platform cooperatives built on blockchain protocols that secure transparency and trust. "While the unimaginative big businesses of today see in the Internet a new way to automate labor, devalue human contributions, securitize wealth, build platform monopolies, and stage spectacular exits, stakeholders in tomorrow's economy should be able to see an opportunity to participate in self-sustaining, highly reciprocal, peer-to-peer, worker-owned, and community-defined marketplaces" (Ibid., 224-225). In this context, distributism does not simply mean decentralisation, but the diffusion of power throughout the network in such a way that value, energy and resources are available to anyone. Distributism should not be confused with any sort of wealth redistribution through state mechanisms, as it aims at the most possible distribution of the means of production to the public.

\subsection{The Anti-Capitalist Theory of the Commons}

The criterion under which I classify the work of Hardt and Negri, De Angelis, Federici, Caffentzis, Rigi and Meretz under the term 'anti-capitalist' is that they all contrast the liberal and reformist theories by placing the Commons in a constant class struggle with capitalism, aiming at the creation of a Commons economy against and beyond capitalism.

The term "class struggle", firstly coined by Marx, represents the economic and political struggles of the different interest groups of society over the millennia. Marx defines as a negative landmark in the history of the class struggle the process of 
primitive accumulation occurring primarily in $17^{\text {th }}$ century England, causing the enclosure of the common lands. For wool to be commoditised and sold to markets, the peasants had to be violently expelled from their ancestral lands, and those lands turned into private property used exclusively for sheep farming. The peasants in turn became proletarians exploited in factories by the emerging industrial capital. As such, capitalism can be considered a counter-reaction of the ruling class against the antifeudal struggles marking the end of the middle ages (Federici 2004). But primitive accumulation was not a unique moment in history as Marx claimed. Luxemburg argued that the enclosure of the commons is an ongoing process essential to the reproduction of capitalism per se (2013 [1913]). Harvey (2003) termed this process "accumulation by dispossession". Capitalism expands by imposing property rights on the various commons such as land, information, knowledge and culture (lbid.). Hardt and Negri's notion of the multitude represents precisely the evolution of the class struggle within and beyond the factory settings, enhanced by the development of information and communication technologies. In this extended setting, the capital and the Commons feed off each other constantly (Hardt and Negri 2000; 2004; 2009). The capital expropriates land and biogenetic content, commoditises citizens' sociality, and uses free software for profit maximisation, while programmers and commoners make use of 'fixed' capital for their own benefits. Bauwens conceives, for instance, the investment of IBM in Linux as a proto-mode of hybrid "capitalistic Commons" that benefit both capitalism and the Commons. In his view, Commonsbased peer production can develop within the capitalist production and replace capitalism in the long run just as capitalism did feudalism (2014c, 33-36).

De Angelis, Federici and Caffentzis reject the "capitalistic Commons" proposed by Bauwens in the fear of the Commons being co-opted by market mechanisms (De Angelis 2007; 2012; Caffentzis 2013; Caffentzis and Federici 2014). They argue that the digital or immaterial Commons cannot have an autonomous substance in their own right, as they depend for their reproduction on both capitalism and the material commons. The digital or immaterial Commons should connect instead to the material Commons and form an alliance of anti-capitalistic Commons developing against capitalism. They regard the Commons as "an association of free individuals" built in terms of "commoning", that is, constitutive social practices of self-governance based on autonomy, equality, reciprocity, collective decision making, and power from the ground up (Caffentzis and Federici 2014, 101). Federici (2012), in particular, represents a feminist approach of the Commons highlighting the gender differences inherent in capitalist production that often go unnoticed in classical Marxism.

All three recognise that the Commons are transitional forms since they cannot do away with capitalist structures all at once, and once and for all. The relation thus of the Commons with capitalism will necessarily involve occasional deals. They do not develop, however, a 'concrete' plan of how this gradual disentanglement of the Commons from capitalism can occur. They advocate a continuous class struggle of the commons with capitalism, but they do not indicate what form this class struggle can take in relation to the state and capitalism. Interestingly, they point to the inherent contradictions of the Commons, such as disorganisation, disempowerment, claustrophobia, patriarchy, xenophobia, racism and gated communities; but they do not present any definite proposal for overcoming these contradictions.

Rigi, on the other hand, develops a concrete alternative alongside a robust critique of the reformist theory. From a Marxist standpoint, Rigi claims that Bauwens and Kostakis' project of open cooperativism perpetuates capitalism inasmuch as it adheres to the capitalist categories of the market, commodity, surplus-value, profit 
and capital. He argues that the introduction of the PPL by Bauwens and Kostakis results in the commodification of the Commons. Bauwens and Kostakis justify the keeping of rent through the PPL by arguing that the GPL allows the capitalists to have a free ride on the Commons. But Rigi considers this untrue. He holds that software/knowledge/information, whether proprietary or free, has zero value. Capitalists thus cannot make extra profit by using free software:

"But to the extent that capitalists are paying a fee to the cooperative for using knowledge this fee is a rent that is part of the surplus-value produced by the total social labor exploited by the total social capital. Hence, the cooperative exploits other workers by extracting surplusvalue from them (...) To sum up the cooperative is implicated in the capitalist mechanism of exploitation either as an exploited or exploiting party in both the processes of the formation of values and that of the production of prices of the commodities they produce" (Rigi 2014, 395).

Rigi considers instead the GPL as the first universal form of communism, saying that "communism is nothing but realisation of individual potentials through voluntary participation in social production and making the product available to all members of society regardless of their contributions" $(2014,399)$. Moreover, the GPL is not just a form of general reciprocity, but inherently results in cooperation given its productive orientation. Rigi perceives the Linux model of production, based on the GPL, as the form of cooperation that subverts the capitalist division of labour both in space and time. Furthermore, he stresses that the GPL/Linux model can be applied to material production by means of digital copying and automation. GPL-oriented production can become the platform of a revolutionary social struggle of peer-producing cooperatives which will reduce their relations to the market to a minimum, while aiming towards a massive exodus from the city to the Commons. The transition from capitalism to the Commons requires the transformation of strategic means of production, namely land and major instances of fixed capital, into Commons.

Similarly, Meretz claims that the introduction of the PPL by Bauwens and Kostakis deals only with the distribution of the surplus value, leaving untouched the production of the commodity and the exchange logic itself. The PPL has nothing to do with "direct reciprocity" since it reproduces the commodity exchange of capitalism. In this way, PPL is trapped into a capitalist-like perspective. Open cooperativism is doomed to bend to the pressures of competition and take part in the process of exploitation. Meretz objects, therefore, to the commoditisation of the Commons through the PPL and argues in favour of an open-code peer-to-peer production that would gradually replace capitalism without the support of an intermediate state (2014). Meretz holds that even the GPL is not communist, because it is exclusionary. He calls instead for an unconditional voluntary reciprocity based on open code that could help pass from an economy of money to a utopia beyond money, commodity, scarcity, labour and the state (2012). 


\section{Reform or Revolt?}

What both the liberal and the anti-capitalist versions of the Commons (with the exception of Rigi) miss is the likelihood of technology bridging the gap between material and immaterial production, thus challenging the monopoly of capitalism on the means and resources of production. The combination of the Internet, free software, 3D printers and artificial technology may render large-scale material production redundant, forcing corporations to adapt in the long run to the decentralisation and commonification of production (Kohtala 2016; Kostakis et al. 2015). Therefore, the model of an open cooperativism between ethical market entities, the partner state and the Commons carries significant potential for the future development of the Commons, since corporatism and the state are not going to wither away anytime soon.

We should be aware, though, of the Commons falling prey to a technological determinism translating everything into a technological fix or an algorithmic governance. There is no such thing as a neutral form of technology. Technology always embodies the social imaginary significations attached to its specific use (Castoriadis 1978, 301-324). Rather than thinking of history in terms of a technological evolution altering the modes of production (Marx, Schumpeter) or exchange (Karatani), it is better to consider it a creation ex nihilo unfolding in the form of the social imaginary significations materialised in concrete technological embodiments. History, as such, reflects the multi-modalities of production and exchange invested by the imaginary significations of society that are neither reducible nor deducible to, or by, any sort of determinism (Castoriadis 1987). The imaginary, as manifested in culture, art, politics, customs, religion, techno-science, economy, etc., does not constitute a reversed form of determinism, but a stratum of Being coexistent among the indeterminate self-creation of nature, developing, among others, on the human models of morality, and formulating both production and exchange (Papadimitropoulos 2014). Instead of thinking of class struggle in terms of a fixed set of modes clashing with one another, it is better considered in terms of the evolution of institutions, which incorporate a fluid and diverse set of values, floating across an ever-changing spectrum of power relations.

The emergence of affect as indicator of value, then, is not due to the technological innovations of industrial and cognitive capitalism that intensified the class struggle by enhancing the productive capacities of the human intellect. Rather, the opposite is true: affect is one of the main drives of the living being's imaginary from its 'inception'. Most importantly, the generalised connection of affect to production presupposes a dangerous economism, reproducing the alienation of capitalism into the tyranny of communism.

If we want to eliminate the repressive reality of capitalism that Marx, Reich, Foucault, Deleuze, Marcuse, Castoriadis and many more described; to reduce the necessary working time to a minimum and maximise 'free' time; to eroticise society and the body, and shape society and humans by Eros and the emergence of affectional social relations (Fuchs 2014, 39), then we must integrate economic value into an intersubjective imaginary non-subject to the rational mastery of an absurd quantification; because every quantification implies a qualification which is nonsusceptible solely to mathematical logic. As Hume long ago argued, Reason is just a means to the end of Passion (2003 [1738]). Rather than counting affect with numbers we ought to measure value with affect in terms of eco-social qualifiers such as sustainability, co-creation, co-operation, co-production and co-consumption. What is 
value and how it is distributed would be democratically decided by the self-evaluation of the groups in question.

In this context, Ostrom's design principles provide a reliable organisational basis, sustaining both reformist and anti-capitalist Commons, as the potential dominance of either form of capitalism cannot render obsolete the class struggle itself. Yet Caffentzis is more than right when he argues that the Commons are much more than Ostrom's principles insofar as they incorporate individual and collective autonomy into a much broader spectrum of political action, bringing together economy, sustainability and democracy. In contrast also to Benkler, autonomy surpasses the limited spaces of production, consumption, culture and entertainment by expanding into the political self-governance of society as a whole. Freedom is not just the negative/neutral institutional demarcation of one's individual space, but the positive definition of one's subjective values with respect to the collective values of the community. The only question, then, concerns whether one is to defend a reformist or an anti-capitalist version of the Commons with respect to the future of the class struggle.

What the anti-capitalist version misses in comparison to the reformist is a 'realistic' plan of a transition from capitalism to the commons. Even Rigi's concrete alternative is inefficient, since the conditions at present do not permit a revolutionary approach that could be backed by a significant portion of the population. By contrast, countless projects in both the material and immaterial commons (Wikipedia, Wikicar, Open Source Ecology, RepRap, Goteo, the Bologna Project, the Catalan Integral Cooperative, Transition Towns, Arduino, Fairmondo, Enspiral, Sensorica, Las Indias, Ethos, Linux, and many more) testify to the potentials inherent in the model of open cooperativism for the future development of the Commons.

In this context, the role of the PPL or any democratic form of financialisation of the Commons like the ones described by Bollier is essential, since it could bring about a transvestment from capitalism to the Commons. Rigi's argument that the Commons exploit their contributors by renting their surplus value to capitalism is not true, given that the profit is redistributed within the Commons. Bauwens and Kostakis perceive the Commons in terms of the medieval guilds or the Enspiral project, in which groups externally trade their goods in the marketplace, while acting internally as solidarity systems that redistribute their income in new projects through a collaborative funding process. Besides, Rigi himself concurs with a minimum cooperation with the market, given that we cannot avoid but coexist within capitalism - at least for the time being.

We cannot at present - despite the desire of Meretz - pass from an economy of money to a utopia beyond money, commodity, scarcity, labour and the state. On the contrary, the state can potentially facilitate the transition from capitalism to the Commons by various means: education, infrastructures, legal systems, and so on. To create a more autonomous, just and equal society, we need to transfer resources (money, infrastructures, human capital) from capitalism to the Commons, and this can happen either in a reformist or a revolutionary way. Both formats can combine depending on the conditions of the class struggle. Whereas the reformist approach is the most realistic at present, a potential crisis of capitalism or the evolution of technology can render the revolutionary approach more feasible.

In any case, the Commons, as De Angelis, Caffentzis and Federici correctly mention, suffer from significant contradictions. Castoriadis, among others, observes that the basic structural contradiction of capitalism, reproduced by the state itself, is the division between directors (managers) and executants (workers) (Castoriadis 1988). Weber, on the other hand, argues for the inevitability of bureaucracy and the limited 
scope of collective self-management in contemporary societies (Kreiss, Finn and Turner 2011). Yet the Internet and free and open source software offer today an immense potential for the creation of a participatory culture based on autonomy and cooperation. However, the Commons are still in their infancy, with the division between managers and executants penetrating them in multiple forms. Elitism, aristocracy, monarchy, autocracy, lack of transparency and solidarity, exclusion, discrimination, racism, precarious volunteering and activism (Scholz 2012; Scholz and Schneider 2016, 38-42), the domination of self-interest and competition over solidarity and cooperation, the rational mastery of techno-economism (Papadimitropoulos 2016) and the fear of the tyranny of the Commons over the heterogeneity of individuality are the contradictions that the Commons face today.

Bauwens (2014b) admits that peer-to-peer projects are said to be, most often, "benevolent dictatorships", controlled by a core of founders on the basis of their larger input into the constitution of the project. This model, of course, is totally incompatible with communal shareholding and his own example of the hunter eating last from his prey. Hierarchy translates often into the obscurity of power. What's more, most of the so-called decentralised autonomous projects developed on the Blockchain infrastructure seem to be rather libertarian than Commons-based.

For these reasons, I hold that transparency of information, distribution of value, solidarity and bottom-up self-management are the core variables of individual and collective autonomy inasmuch as they permit a community or group to formulate its values in relation to the needs and skills of its members. Transparency in terms of open accounting, open protocols and open supply chains, as proposed by Bauwens, is the sufficient condition for incorporating competition into an economy based on cooperation and trust. Cooperation is not to be forced in any way, but we still need to have free access to all information available in order to be truly autonomous in our judgements and choices. Transparency is the necessary and sufficient condition of individual and collective autonomy.

I agree with Bauwens that the key issue is the balance between efficiency and participation; we need not waste time in endless deliberations in search for a "final" consensus (Bauwens 2014b). It is essential, however, to abolish the distinction between directors and executants in order to wipe out the capitalist imaginary that penetrates the Commons in multiple forms. Following Castoriadis, freedom is the equality of all in participating in the formation of the law ruling society. Freedom is the equality of autonomy for individuals thinking and acting within collectivities. Therefore, we should be aware of the danger of a reversed bureaucracy that could result either in the oligarchy of a technocratic elite or in the tyranny of the Commons, both oppressing equally the heterogeneity of individuality inherent in the cultural diversity of any collectivity.

\section{Conclusion}

In this paper I have presented a critical overview of the contemporary political theories of the Commons, classified in three main categories: the liberal, the reformist and the anti-capitalist. The work of Ostrom, Benkler and Bollier is termed 'liberal' insofar as they place the development of the Commons in parallel with the state and market operation. The work of Bauwens and Kostakis, Arvidsson and Peitersen and Rushkoff is termed 'reformist', as they advocate the gradual adjustment of capitalism to the Commons. The work of Hardt and Negri, De Angelis, Caffentzis, Federici, Rigi and Meretz is termed 'anti-capitalist', given that they favour the autonomous development of the Commons against and beyond capitalism. 
I argue that both the liberal and the anti-capitalist theorists (with the exception of Rigi) miss the likelihood of the Internet, 3D printers and artificial technology rendering large-scale material production redundant, thus forcing capitalism to adjust to the Commons in the long run. I therefore make the case that the reformist theory has significant potential for the future development of the Commons. I stress, however, the fact that the Commons are still in its infancy facing numerous 'internal' contradictions such as elitism, aristocracy, monarchy, autocracy, lack of transparency and solidarity, exclusion, discrimination, racism, precarious volunteering and activism, the domination of self-interest and competition over solidarity and cooperation, the rational mastery of techno-economism, and the fear of the tyranny of the Commons over the heterogeneity of individuality. For the Commons to overcome these contradictions, a global institutional reform, followed by a number of inter-local and international principles, is sine qua non. In this framework, transparency of information, distribution of value, solidarity and bottom-up self-management are the core variables of individual and collective autonomy, as they permit a community or group to formulate its values in relation to the needs and skills of its members.

\section{References}

Arvidsson, Adam and Nicolai Petersen. 2013. The Ethical Economy: Rebuilding Value After the Crisis. New York: Columbia University Press.

Bauwens, Michel. 2005. The Political Economy of Peer Production. C-Theory: 1000 Days of Theory. 1 December. Accessed May 16, 2016. http://www.ctheory.net/articles.aspx?id=499

Bauwens, Michel. 2014a. Towards the Democratization of the Means of Monetization: The Three Competing Value Models Present Within Cognitive Capitalism. The Journal of Peer Production 4.

Bauwens, Michel. 2014b. The Rise of Multistakeholder Cooperatives. Shareable. Accessed May 16, 2016. http://www. shareable.net/blog/michel-bauwens-on-the-rise-of-multistakeholder-cooperatives

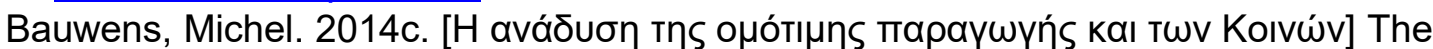
Emergence of the Peer-to-Peer Production and the Commons. In [Пદ́pa aпó то кра́тоऽ ка।

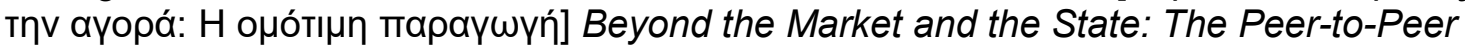

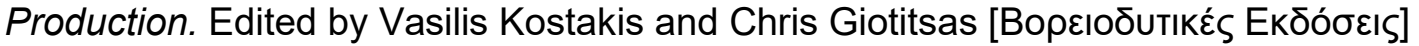
loannina North-western Editions.

Bauwens, Michel. 2015. Critique of the Peer Production License. Peer-To-Peer Foundation Net. Accessed May 16, 2016, http://peer-topeerfoundation.net/Critique of the Peer Production License

Bauwens, Michel. 2016a. Why the P2P and Commons Movement Must Act Trans-Locally and Trans-Nationally. Accessed April 12, 2017. https://blog.p2pfoundation.net/p2pcommons-movement-must-act-trans-locally-trans-nationally/2016/06/16

Bauwens, Michel. 2016b. The Evolution of Modes of Exchange in the Context of P2P Theory. Accessed April 10, 2017. http://wiki.p2pfoundation.net/Evolution of the Structure of World History Through Mod es of Exchange

Bauwens, Michel and Vasilis Kostakis. 2014. From the Communism of the Capital to the Capital for the Commons: Towards an Open Cooperativism. tripleC: Communication, Capitalism \& Critique. Open Access Journal for a Global Sustainable Information Society 12(1): 356-361.

Bauwens, Michel, and Vasilis Kostakis. 2015. Towards a New Reconfiguration Among the State, Civil Society and the Market. Journal of Peer Production 7. 
Bauwens, Michel Vasilis Kostakis and Alex Pazaitis. 2016. Towards a Society of the Commons. In The Enigma of Europe: Transform! yearbook 2016, edited by Walter Baier, Eric Canepa and Eva Himmelstoss. Pontypool: Merlin Press Ltd.

Bauwens, Michel and Vasilis Niaros. 2017. Value in the Commons Economy: Developments in Open and Contributory Value Accounting. Heinrich Böll Stiftung, P2P Foundation.

Benkler, Yochai. 2003. Freedom in the Commons: Towards a Political Economy of Information. Duke Law Journal 55 (6): 1245-1276.

Benkler, Yochai. 2006. The Wealth of Networks: How Social Production Transforms Markets and Freedom. New Haven: Yale University Press.

Bollier, David and Burns H. Weston. 2012. Green Governance: Ecological Survival, Human Rights and the Law of the Commons. In The Wealth of the Commons: A World Beyond Market \& State, edited by David Bollier and Silke Helfrich, 343-352. Amherst: Levellers Press.

Bollier, David and Silke Helfrich, eds. 2015. Patterns of Commoning. Amherst: Off the Common [Levellers Press].

Broumas, Antonios. 2017. Social Democratic and Critical Theories of the Intellectual Commons: A Critical Analysis. tripleC: Communication, Capitalism \& Critique. Open Access Journal for a Global Sustainable Information Society 15(1): 100-126.

Caffentzis, George. 2013. In Letters of Blood and Fire: Work, Machines and the Crisis of Capitalism. Oakland: PM Press.

Caffentzis, George and Silvia Federici. 2014. Commons Against and Beyond Capitalism. Community Development Journal 49: 92-105.

Castells, Manuel. 2000. The Information Age: Economy, Society and Culture, Volume I: The Rise of the Network Society. Oxford: Blackwell.

Castells, Manuel. 2009. Communication Power. New York: Oxford University Press.

Castoriadis, Cornelius. 1978. Les Carrefours du Labyrinth. Paris: Éditions du Seuil.

Castoriadis, Cornelius. 1987. The Imaginary Institution of Society. Cambridge: Polity Press.

Castoriadis, Cornelius. 1988. On the Content of Socialism II. In Political and Social Writings Vol. 2, translated and edited by David Ames Curtis, 90-154. Minneapolis: University of Minnesota Press.

Castree, Noel. 2010. Neoliberalism and the Biophysical Environment. Environment and Society: Advances in Research 1: 5-45.

Conaty, Pat and David Bollier. 2014. Toward an Open Cooperativism: A New Social Economy Based on Open Platforms, Co-Operative Models and the Commons. Report given during workshop hosted by the Commons Strategies Group, Berlin, 27-28 August.

Corcoran, Paul E. 1983. Before Marx: Socialism and Communism in France, 1830-1848. London: MacMillan Press.

De Alessi, Michael. 1998. Fishing for Solutions. London: Institute of Economic Affairs.

De Angelis, Massimo. 2007. The Beginning of History: Global Capital and Value Struggles. London: Pluto Press.

De Angelis, Massimo. 2012. Crises, Capital and Cooptation: Does Capital need a Commons Fix? In The Wealth of the Commons: A World Beyond Market and State, edited by David Bollier and Silke Helfrich. Amherst: Levellers Press.

Federici, Silvia. 2004. Caliban and the Witch: Women, the Body and Primitive Accumulation, Brooklyn: Autonomedia.

Federici, Silvia. 2012. Revolution at Point Zero: Housework, Revolution and Class Struggle, New York: PM Press.

Foucault, Michel. 1977. Discipline and Punish: The Birth of the Prison. New York: Pantheon Books.

Fuchs, Christian. 2014. Digital Labour and Karl Marx. London: Routledge.

Hardin, Garrett. 1968. The Tragedy of the Commons. Science 162: 1243-1248.

Hardt, Michael. 1999. Affective Labor. Boundary 2 (2): 89-100.

Hardt, Michael and Antonio Negri. 2000. Empire. Cambridge, MA: Harvard University Press. 
Hardt, Michael and Antonio Negri. 2004. Multitude: War and Democracy in the Age of Empire. London: Penguin.

Hardt, Michael and Antonio Negri. 2009. Commonwealth. Cambridge, MA: Belknap Press.

Harvey, David. 2003. The New Imperialism. Oxford: Oxford University Press.

Hume, David. 2003 [1738]. A Treatise of Human Nature. New York: Dover Publications, Inc.

Karatani, Kojin. 2014. The Structure of World History, From Modes of Production to Modes of Exchange. Durham: Duke University Press.

Kohtala, Cindy. 2016. "Making Sustainability: How Fab Labs Address Environmental Issues." PhD diss., Aalto University (publication series). Helsinki: Aalto Arts Books.

Kostakis, Vasilis and Michel Bauwens. 2014. Network Society and Future Scenarios for a Collaborative Economy. London: Palgrave Macmillan.

Kostakis, Vassilis, Vassilis Niaros, George Dafermos and Michel Bauwens. 2015. Design Global, Manufacture Local: Exploring the Contours of an Emerging Productive Model. Futures 73: 126-135.

Kreiss, Daniel, Megan Finn and Fred Turner. 2011. The Limits of Peer Production: Some Reminders from Max Weber for the Network Society. New Media \& Society 13 (2): 243259.

Lessig, Lawrence. 2006. Code Version 2.0 [Code and Other Laws of Cyberspace]. New York: Basic Books.

Linebaugh, Peter and Marcus Rediker. 2000. The Many-Headed Hydra: Sailors, Slaves, Commoners and the Hidden History of the Revolutionary Atlantic. Boston: Beacon Press.

Luxemburg, Rosa. 2003 [1913]. The Accumulation of Capital. London: Routledge.

Marx, Karl. 1973 [1939]. Grundrisse: Foundations of the Critique of Political Economy. London: Penguin.

Marx, Karl. 1992 [1885]. Capital: A Critique of Political Economy, Volume II. London: Penguin.

Meretz, Stefan. 2012. Peer Production and Societal Transformation: Ten Patterns Developed by the Oekonux Project. Journal of Peer Production 1.

Meretz, Stefan. 2014. Socialist Licenses? A Rejoinder to Michel Bauwens and Vasilis Kostakis. tripleC: Communication, Capitalism \& Critique. Open Access Journal for a Global Sustainable Information Society 12(1): 362-365.

Negri, Antonio. 1999. Value and Affect. Translated by Michael Hardt. boundary 26 (2): 77-88.

Ostrom, Elinor. 1990. Governing the Commons: The Evolution of Institutions for Collective Action. Cambridge: Cambridge University Press.

Ostrom, Elinor. 2000. Collective Action and the Evolution of Social Norms. Journal of Economic Perspectives 14(3): 137-158.

Ostrom, Elinor. 2012. The Future of the Commons: Beyond Market Failure and Government Regulation. London: The Institute of Economic Affairs.

Perez, Carlotta. 2002. Technological Revolutions and Financial Capital: The Dynamics of Bubbles and Golden Ages. Cheltenham: Edward Elgar.

Papadimitropoulos, Evangelos. 2014. Rational Mastery and Freedom in the Thought of Cornelius Castoriadis, Ph. D. Thesis. Rethymno: University of Crete. Greece (In Greek).

Papadimitropoulos, Evangelos. 2015. Indeterminacy and Creation in the Work of Cornelius Castoriadis. Cosmos and History: The Journal of Natural and Social Philosophy 11 (1): 256-268.

Papadimitropoulos, Vangelis. 2016. The Rational Mastery in the Work of Cornelius Castoriadis. Capitalism, Nature, Socialism 10. doi: 1080/10455752.2016.1267784.

Rigi, Jacob. 2014. The Coming Revolution of Peer Production and Revolutionary Cooperatives: A Response to Michel Bauwens, Vasilis Kostakis and Stefan Meretz. tripleC: Communication, Capitalism \& Critique. Open Access Journal for a Global Sustainable Information Society 12(1): 390-404.

Rushkoff, Douglas. 2016. Throwing Rocks at the Google Bus: How Growth Became the Enemy of Prosperity. New York: Portfolio/Penguin. 
Sen, Amartya. 1977. Rational Fools: A Critique of the Behavioral Foundations of Economic Theory. Philosophy and Public Affairs 6(4): 317-344.

Scholz, Trebor. 2012. Digital Labor: The Internet as Playground and Factory. New York: Routledge.

Scholz, Trebor and Nathan Schneider. 2016. Ours to Hack and to Own: The Rise of Platform Cooperativism, A New Vision for the Future of Work and a Fairer Internet. New York: Or Books.

Swan, Melanie. 2015. Blockchain: Blueprint for a New Economy. Sebastopol, CA: O'Reilly Media.

Van de Walle, Nicolas. 2001. African Economies and the Politics of Permanent Crisis. Cambridge: Cambridge University Press.

\section{About the Author}

Evangelos Papadimitropoulos

Evangelos Papadimitropoulos holds a PhD in Political Philosophy and is an independent researcher. He is currently employed as a copywriter/content manager by an international company based in Amsterdam. 